\title{
Observatório
}

\section{A PUBLICIDADE NO \\ CONTEXTO DA SOCIEDADE \\ DA SENSAÇÃO: um formato \\ comunicacional e a relação \\ percepção/cogniç̧ão em \\ foco}

ADVERTISING IN THE CONTEXT OF THE SENSATION SOCIETY: a communicational format and the relation between perception and cognition in focus

\section{PUBLICIDAD EN EL CONTEXTO DE LA SOCIEDAD SENSACIÓN:} un formato de comunicación y el foco relación de la percepción/la cognición

\section{Maria Ogécia Drigo ${ }^{1,2}$}

\section{RESUMO}

O objetivo deste artigo é refletir sobre a cognição em meio a um contexto permeado por choques audiovisuais e no qual as representações visuais estão incessantemente em cena. Para tanto, consideram-se as transformações da relação percepção/sensação no contexto da sociedade da sensação, na perspectiva de Christoph Türcke, bem como conceitos da arquitetura filosófica de Charles Sanders Peirce, principalmente a classificação dos signos em hipoícones e suas diversas modalidades e o movimento percepção/cognição nos diversos níveis de consciência Da confluência dessas ideias conjeturamos

\footnotetext{
${ }^{1}$ Doutorado em Comunicação e Semiótica pela Pontifícia Universidade Católica de São Paulo (PUC-SP). Mestrado em Educação Universidade Metodista de Piracicaba (UNIMEP). Graduação em Matemática pela Universidade de Sorocaba (UNISO). Pós-doutorado em Comunicação pela Universidade de São Paulo (USP) e pela Universidade de Kassel (Alemanha). Coordenadora do GPIM -Grupo de Pesquisa em Imagens Midiáticas. E-mail: maria.ogecia@gmail.com.

2 Endereço de contato da autora (por correio): Universidade de Sorocaba, Centro de Ciências Exatas e Tecnológicas. Rodovia Raposo Tavares, Km 92,5, Artura, CEP: 18023-000, Sorocaba, SP, Brasil.
} 


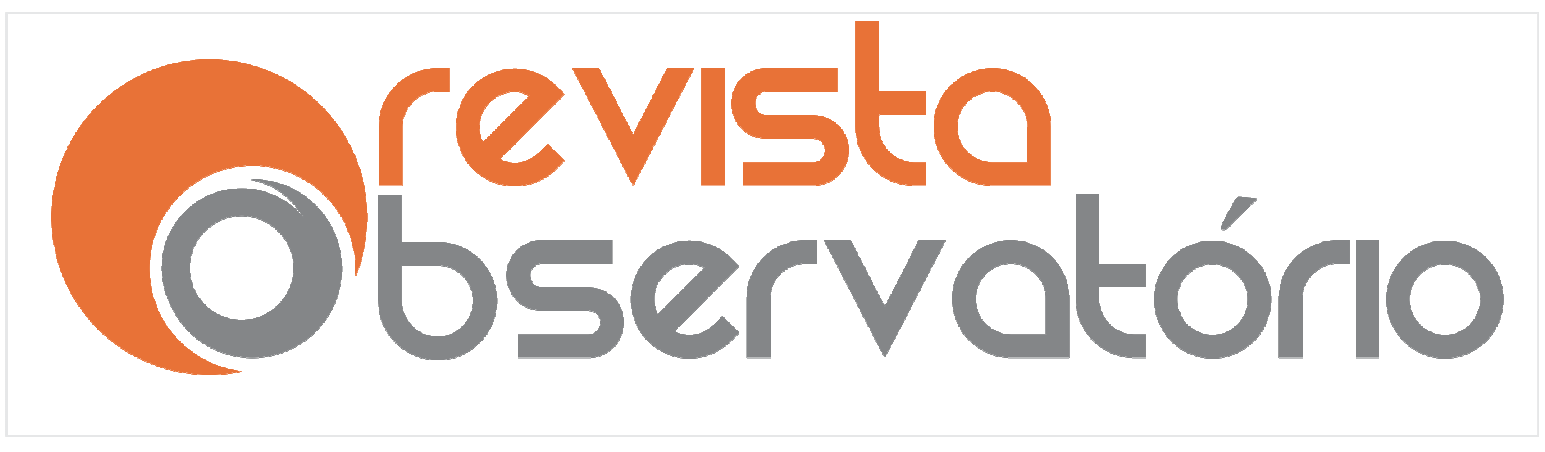

ISSN n² 2447-4266

Vol. 3, n. 3, Maio. 2017

DOI: http://dx.doi.org/10.20873/uft.2447-4266.2017v3n3p415

sobre a importância da síntese e da construção de signos (objetos) que problematizem a relação ícone/índice, tarefa esta que cabe aos produtores (forjadores) de signos, entre eles, os designers e os publicitários.

PALAVRAS-CHAVE: Sociedade da sensação; Publicidade; Percepção/cognição; Síntese; Diagrama.

\section{ABSTRACT}

This paper aims to reflect on cognition within a context permeated by audiovisual clashes, since visual representations are incessantly on the scene. Thereto, one considers the transformations of the relation between perception and sensation within the context of the society of sensation, in Christoph Türcke's perspective, as well as concepts from Charles Sanders Peirce's philosophical architecture, chiefly the classification of signs in hypoicons and its diverse modalities, and the movement perception/cognition through the different levels of consciousness. From the confluence of such ideas, we conjecture about the importance of the synthesis and of the construction of signs (objects) that may problematize the relation icon/index, a task that is assigned to producers (forgers) of signs, among which, the designers and advertising professional.

KEYWORDS: Society; sensation; Advertising; Perception/cognition; Synthesis; Diagram.

\section{RESUMEN}

El objetivo de este artículo es reflexionar sobre la cognición en promedio a un contexto permeado por choques audiovisuales, porque las representaciones visuales están incesantemente en escena. Se van a considerar para ello las transformaciones de la relación entre la percepción y la sensación en el contexto de la sociedad de la sensación, bajo la perspectiva de Christoph Türcke, pero también conceptos de la arquitectura filosófica de Charles Sanders Peirce, principalmente la clasificación de los signos en hipo íconos y sus 


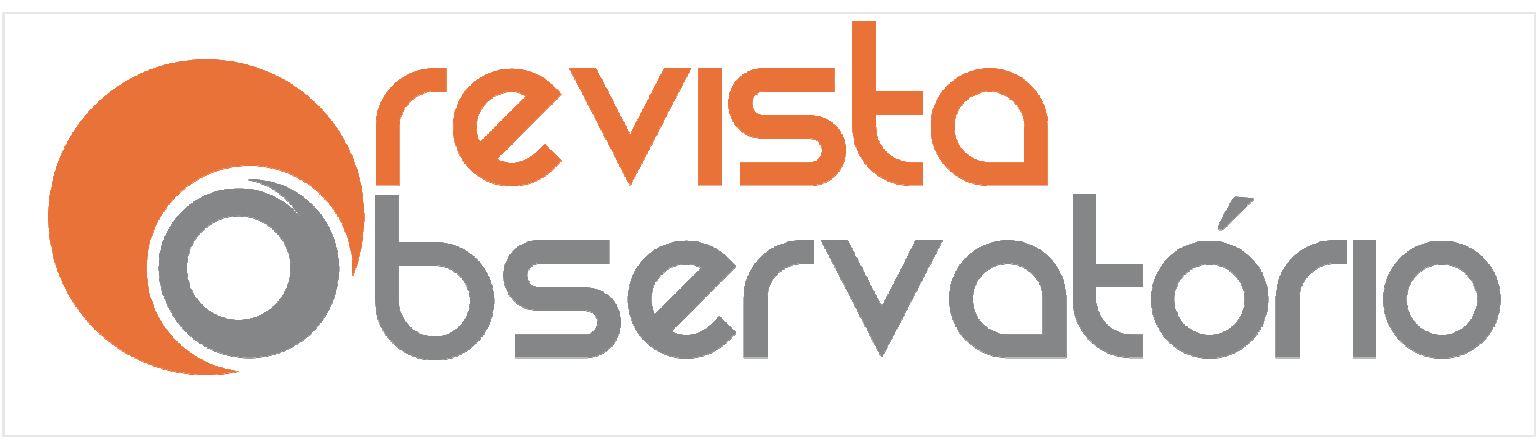

ISSN n² 2447-4266

Vol. 3, n. 3, Maio. 2017

DOI: http://dx.doi.org/10.20873/uft.2447-4266.2017v3n3p415

diversas modalidades y el movimiento percepción/cognición por los diversos niveles de la consciencia. De la confluencia de esas ideas se va a conjeturar sobre la importancia de la síntesis y de la construcción de signos (objetos) que problematicen la relación iconicidad y lo que se indicia, tarea esa que cabe a los productores (forjadores) de signos, entre ellos, los diseñadores y los publicitarios.

PALABRAS CLAVE: La sociedad del sentimiento; Publicidad; La percepción/cognición; Síntesis; Diagrama.

Recebido em: 15.01.2017. Aceito em: 20.04.2017. Publicado em: 01.05.2017. 


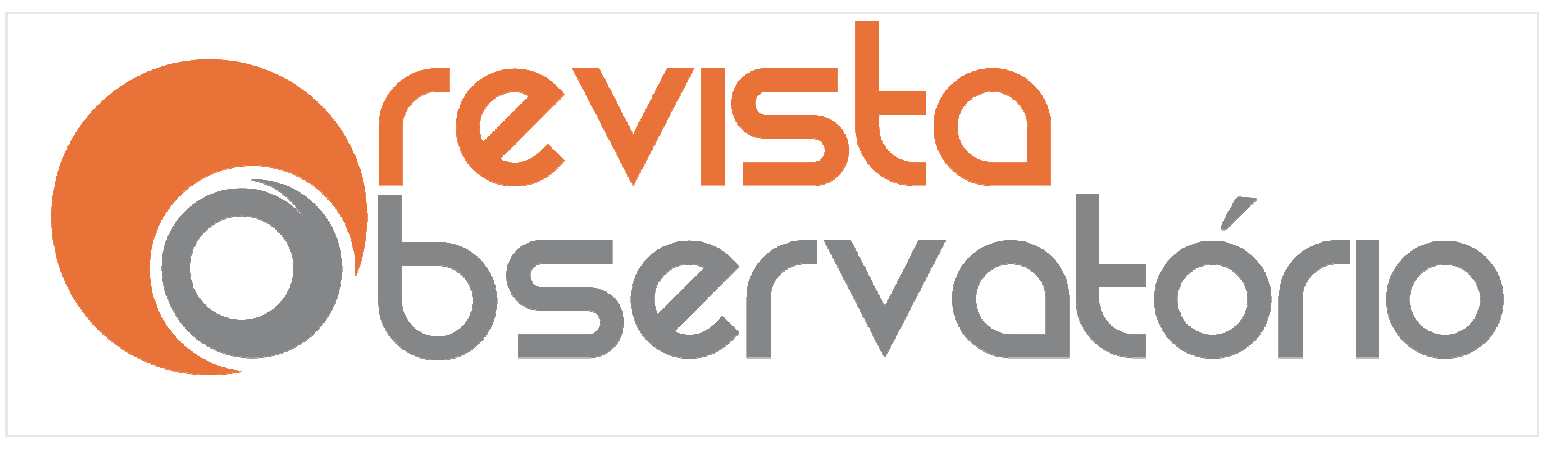

ISSN n² 2447-4266

Vol. 3, n. 3, Maio. 2017

DOI: http://dx.doi.org/10.20873/uft.2447-4266.2017v3n3p415

\section{Introdução}

Este artigo tem como contexto a "sociedade da sensação", na perspectiva de Türcke (2010). Com o objetivo de avaliar as possibilidades da cognição emergir nessa seara permeada por choques audiovisuais, a qual leva a transformações da percepção, iniciamos com ideias do filósofo alemão, Christoph Türcke, e delas tomamos a máxima de que a forma comunicacional que reina nesse meio é a da publicidade. Em seguida, considerando-se que a percepção pertinente à cognição não seria a que envolve choques audiovisuais reiterados incessantemente, buscamos contribuições no pensamento peirceano para tratar de modos de representação - ou tipos de signos - propícios para amenizar ou até mesmo dirimir os efeitos desses choques audiovisuais incessantes.

Deste modo, vem com Türcke (2010), de um lado, a ideia de que o comercial tornou-se a "forma comunicacional mais pregnante"; de outro, a necessidade de vencer a luta pela percepção, uma vez que ela se dissipa em meio a uma quantidade imensa de estímulos audiovisuais. Seguindo a trajetória que estipulamos para este artigo, então, cabe a pergunta: Que ideias peirceanas podem contribuir para a elaboração de tal formato comunicacional, em concordância com o que impregna nosso meio, mas com potencial para vencer a luta pela percepção? Daí segue, como uma possível resposta à questão anunciada, os signos denominados hipoícones e a importância de que estes problematizem a conexão com o real e o poder dos aspectos qualitativos do objeto nessa modalidade de representação.

Seguem aspectos da sociedade da sensação, do ponto de vista de Türcke. 


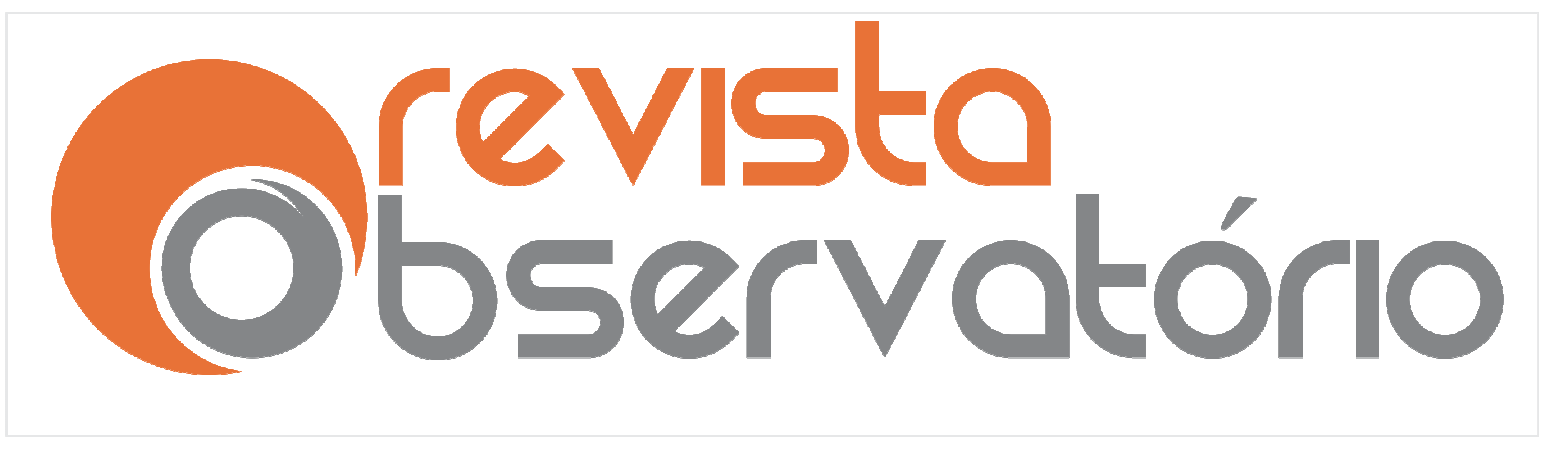

ISSN n² 2447-4266

Vol. 3, n. 3, Maio. 2017

DOI: http://dx.doi.org/10.20873/uft.2447-4266.2017v3n3p415

\section{A Forma Comunicacional Determinada Pela Publicidade}

A sociedade moderna, com todo seu progresso técnico e científico, acabou por minar, segundo Türcke (2010: 9), "relações de trabalho, de propriedade e patrimoniais, hábitos superados, rituais, fundamentações de crenças, ritmos e extensões de vida comuns, velocidade, formas de pensamento e de percepção". Esta sociedade se caracterizou como um estado de inquietude geral, de efervescência, bem como extremamente promissora, notadamente nos séculos XVIII e XIX. Com a Revolução Industrial, para Türcke (2010: 10), "abriuse, concomitantemente, a perspectiva de uma nova época direcionada pela razão, na qual as pessoas agiriam coletivamente de forma solidária e produtiva, tal como demonstraram as muitas partes entrelaçadas de uma grande engrenagem maquinal". No século $X X$, constata-se que isto não se deu, contudo, a efervescência não cessou. $E$, ainda mais, agora está a nossa disposição um repleto aparato visual.

Türcke (2010: 10) enfatiza que chegou "o momento de se falar de uma sociedade da sensação", termo que não designa uma nova época, tal como sociedade pós-industrial, pós-moderna, sociedade de risco, da informação, pois o fato das máquinas não mais exalarem vapor ou não levarem os trabalhadores à fadiga, não quer dizer que esta não seja ainda uma sociedade industrial. Esta ainda é uma sociedade industrial, que "penetra microeletronicamente, com sua produtividade múltipla e refinada, em todas as áreas de trabalho" (TURCKE, 2010: 10). Vale enfatizar ainda que a informação é importante, mas ela também foi para a criação de um comércio á distânica, que precisava de informações confiáveis. Do mesmo modo, não só agora há riscos, pois as sociedades arcaicas foram expostas aos animais selvagens, às epidemias e à fome. 


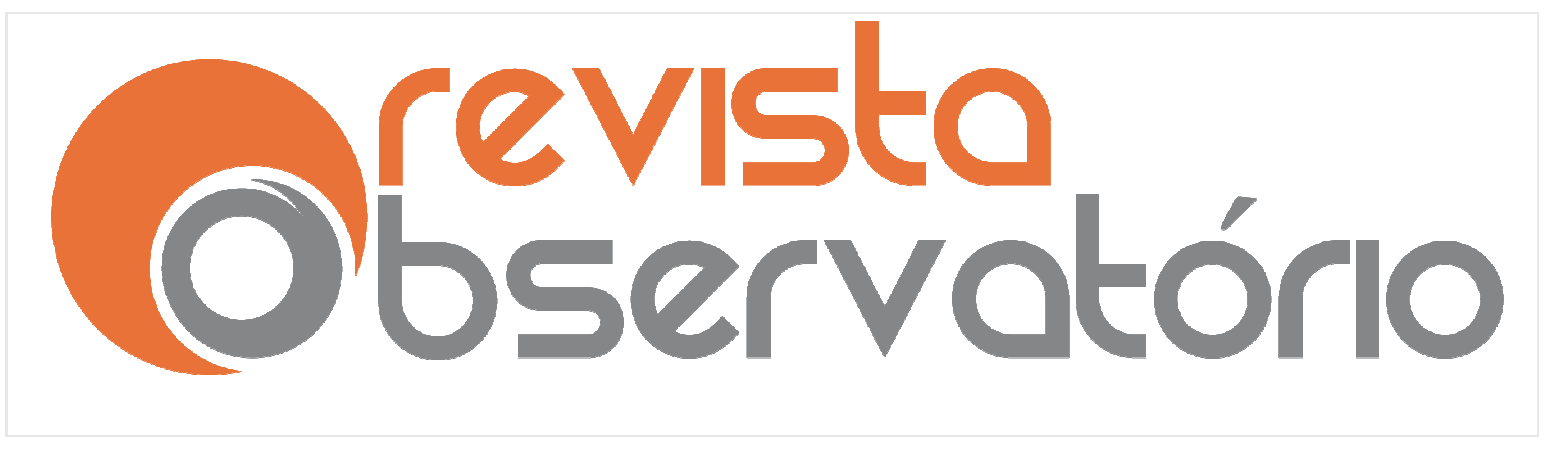

ISSN n² 2447-4266

Vol. 3, n. 3, Maio. 2017

DOI: http://dx.doi.org/10.20873/uft.2447-4266.2017v3n3p415

Nesse movimento de colocar uma característica preponderante de determinada época para caracterizá-la, o autor menciona Guy Debord e a "sociedade do espetáculo". Segundo Türcke (2010: 11), Debord tratou do "espetáculo midiático como espetáculo de feira transformado, o chamativo audiovisual como propaganda alavancada de mercadorias, o culto imagético como fetichismo da mercadoria estetizado, o moderno como o apogeu do arcaico". O autor retoma o caminho de Debord e analisa o movimento das notícias - dos panfletos esporádicos às telas da TV-, a programação da TV - com ênfase nos confessional talk e no Big Brother -, bem como alcança o piercing e a tattoo, sem deixar de ressaltar a propaganda, mas analisa-os criticamente, pois Debord, para Türcke (2010: 11), apenas tangenciou o espaço, o tempo e a história como se bastasse "saber o que são o capitalismo e o fetiche da mercadoria e a única coisa que restasse fosse descobrir seus disfarces mais recentes".

Seguimos o percurso de Türcke... A propaganda, para Türcke (2010: 27), encontrou um ambiente para crescer desenfreadamente com a "desregulamentação que submeteu os serviços de infraestrutura elementares como as telecomunicações, o correio, o sistema de transporte ferroviário, rodoviário e aéreo à concorrência geral, auxiliada pela alta tecnologia". Nesse movimento, a propaganda torna-se autorreferencial e irônica, pois coloca o receptor em condições de compartilhar conhecimento e de ser um copensador à espera de prazer que a compra do produto pode oferecer.

Os comercias indicam caminhos de como a informação pode ser transmitida em sua forma mais econômica, porque mais intensiva.

Os políticos anseiam por comunicar, com a brevidade, concisão, e veemência do comercial, aquilo que desejam realizar. Programas de 


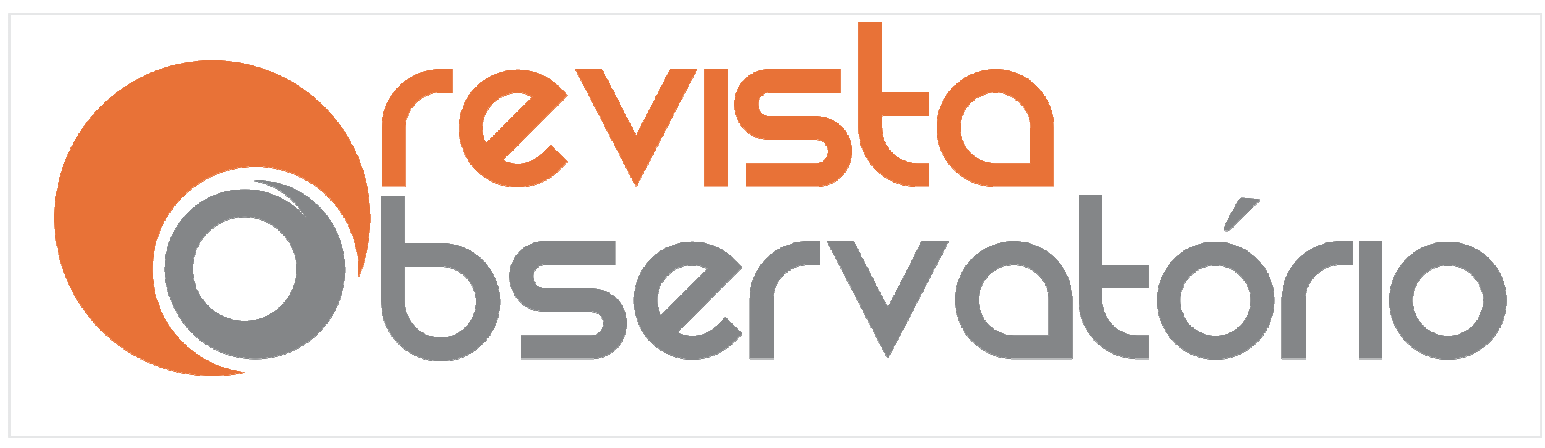

ISSN n² 2447-4266

Vol. 3, n. 3, Maio. 2017

DOI: http://dx.doi.org/10.20873/uft.2447-4266.2017v3n3p415

notícias passam a ser medidos pelo parâmetro de quanto são capazes de satisfazer esse ideal; todo um gênero de curta-metragem noticiários, esportivos, documentários - surgiu tendo o comercial como modelo. Sob condições econômicas de desregulamentação, o comercial converte-se em regulador da informação. (TÜRCKE, 2010: 28)

Explica ainda Türcke (2010: 34), que o comercial tornou-se a forma comunicacional mais pregnante, apesar de não lidar com os fatos e com a verdade. Neste sentido, as notícias, por exemplo, passam a se valer de "imagens, atmosferas, humores, associações - daquele outfit que fornece a cor, a plasticidade, o caráter marcante ao simples e pálidos fatos, sem os quais estes pareciam completamente desamparados".

Segundo Türcke (2010: 37), "o comercial se transforma na ação comunicativa por excelência, ele passa a ser equivalente à presença social. Quem não faz propaganda não comunica; é como uma emissora que não emite; praticamente, não está aí". E ainda mais, a estridente mensagem econômica, que envolve os produtos e as marcas em meio a cores, formas e sons, bem como estilos de vida, passa a ser ouvida com outro tom, o de cunho existencial. A compulsão em emitir "já estava em curso com o advento do telégrafo, do telefone e da televisão. Porém é somente com a alta pressão de notícias dos meios de comunicação de massa - que gera uma compulsão em todos os indivíduos a emitir - que ela adquire o caráter de uma condição existencial" (TÜRCKE, 2010: 46).

Turcke (2010: 41) explica que quem está presente com seu corpo é percebido, no entanto, o estar aí sofre uma "mudança de sentido decisiva a partir do momento em que a presença do corpo desaparece por detrás da presença midiática - basicamente, desde a marcha triunfal do cinema". O que era uma excentricidade dos artistas de cinema e de televisão, em meados do 


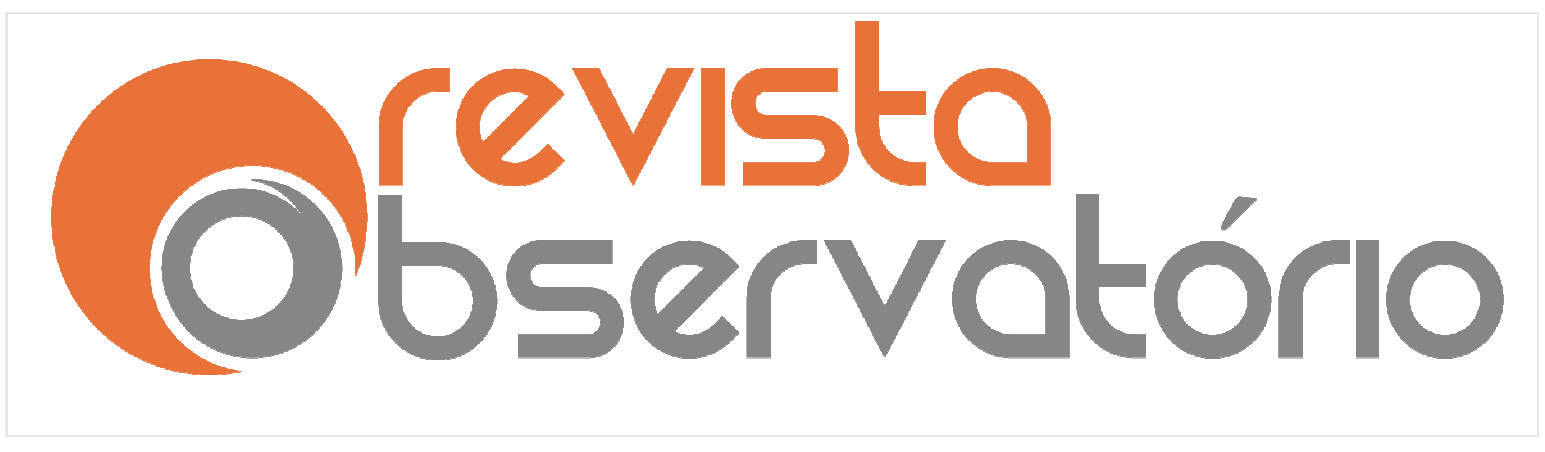

ISSN n² 2447-4266

Vol. 3, n. 3, Maio. 2017

DOI: http://dx.doi.org/10.20873/uft.2447-4266.2017v3n3p415

século $X X$, passa a ser um modo de perceber que se espraia nos dias atuais: "a presença corporal produz um efeito pálido e apagado em comparação com a midiática" (TÜRCKE, 2010: 41-2).

Este movimento requer que se apresentem as transformações da sensação. Conforme explica Türcke (2010: 89), para Aristóteles, "a percepção não é algo que acontece passiva e irracionalmente, mas um trabalho complexo de transformação, no qual os diferentes órgãos sensoriais estão envolvidos". A visão, a audição, o olfato, o paladar e o tato foram tratados pelo filósofo num só conceito de percepção sensorial: aisthesis. No latim da alta idade média, o termo sensatio gradualmente se transforma no termo usual para aquilo que fazem os sentidos.

Para Aristóteles, a percepção sensorial, como infraestrutura do pensamento, permanece-lhe subordinada, enquanto 0 pensamento representado é o único acesso ao verdadeiro ser, à substância ideal do mundo. "Essa avaliação foi seguida pelos intelectuais ocidentais até a alta idade média, praticamente em uníssono" (TÜRCKE, 2010: 89)

As transformações da sensação se acentuam com a curiosidade, que se firmou, no século XV, segundo Türcke (2010: 90), com a busca "profissional por manuscritos antigos, perdidos ou raros, a época na qual se organizavam os jardins botânicos com plantas extraordinárias, a época do surgimento de gabinetes de raridades [...]". Deste modo, o que é raro passa a ser visto como sensacional, mas por ser extraordinário, singular, e não por ser regido por leis incompreensíveis. Assim, tanto a percepção como a atenção adquirem a característica de um apetite que reforça a si mesmo. O interesse pelo raro e pelo novo pode "passar a funcionar sistematicamente, transformando-se no 


\section{Observisto}

ISSN n² 2447-4266

Vol. 3, n. 3, Maio. 2017

DOI: http://dx.doi.org/10.20873/uft.2447-4266.2017v3n3p415

motor de uma forma de apropriação do mundo dotada de vontade própria e avançando por meio de uma realimentação" (TÜRCKE, 2010: 92).

Como explica Türcke (2010: 93), os gabinetes de arte e curiosidades da Renascença foram os primeiros a desencadear esse desenvolvimento, pois colocar "o que não é familiar em um arquivo significa submetê-lo a uma ordem, sob a qual se converte em algo usual". Contudo, as fronteiras para o encontro com o excepcional ampliam-se com as feiras e os mercados que, em oposição aos gabinetes destinados a poucos privilegiados, passam a ser o lugar onde 0 povo se comprimia. "São partes inalienáveis da feira [...] o barulho, a preconização chamativa da própria mercadoria, que tanto mais é necessária para a venda quanto mais aparentemente similar forem as mercadorias. Colocar mercadorias à venda é uma forma de espetáculo" (TÜRCKE, 2010: 96).

As notícias, por sua vez, seguiam as pegadas das mercadorias, no transcorrer dos séculos XIV e XV e vieram a automizar-se quando comerciantes hábeis as transformaram em negócio. A notícia foi definida, então, como tudo aquilo capaz de incitar a atenção de um vasto público, quer fosse fruto da imaginação ou de uma observação, quer fosse provado ou não. No entanto, seria necessário fazer crer que havia acabado de chegar, que estava praticamente presente. "Na época de seu surgimento, os jornais, sem qualquer ética profissional, correspondiam exatamente ao que hoje chamamos de imprensa sensacionalista" (TÜRCKE, 2010: 98). Isso não deixou de ser notado, no entanto, não foi relacionado ao conceito de sensação, que para nós hoje é corriqueiro.

Türcke (2010: 98) explica que a "autonomização da novidade em um valor em si, que é acompanhada da realimentação recíproca de curiosidade privada e empresarial, corresponde ao segundo passo decisivo da mudança de 


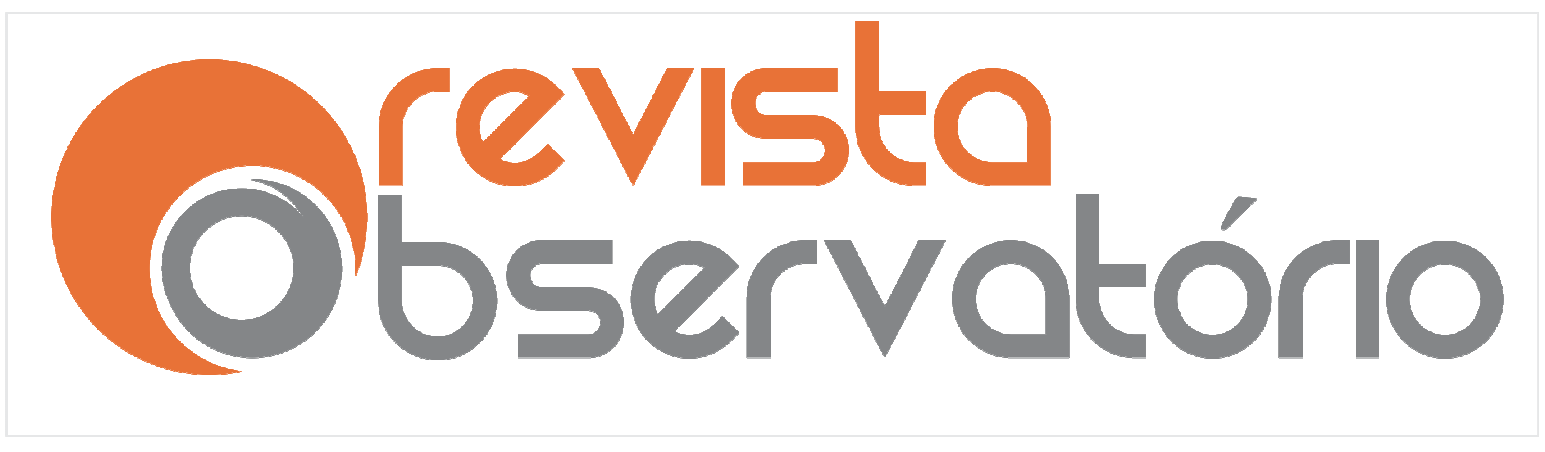

ISSN n² 2447-4266

Vol. 3, n. 3, Maio. 2017

DOI: http://dx.doi.org/10.20873/uft.2447-4266.2017v3n3p415

valor da curiositas." Assim, a percepção passa de um impulso básico para um impulso fisiológico com força sistêmica.

Conforme Türcke (2010: 98), "a palavra sensação não apareceu vinculada à divulgação negligente de notícias, nem ao espetáculo das feiras, nem pela passagem aos gabinetes de maravilhas (curiosidade)", mas veio com a filosofia. Há dois discursos sobre a sensação: o filosófico e o vulgar. O filosófico que fundamenta epistemologicamente, para Türcke (2010: 118), "o processo de percepção, e que continua, depois de Berkeley, passando por Hume, Kant e sua herança sensualista e racionalista, até a moderna fenomenologia, a teoria da Gestalt e a neurofisiologia". O vulgar, por sua vez, gradativamente, conforme Türcke (2010: 119), "reduziu a sensação àquele acontecimento espetacular atuante nas massas, que os filósofos usualmente julgavam como indigno de sua reflexão - com isso, porém, deixando escapar o teor eminentemente filosófico dessa redução".

Com a filosofia de Berkeley, segundo Türcke (2010: 119), a sensação torna-se sinônimo de "aquilo que chama a atenção", com o que "não ocorre simplesmente uma mera redução avessa ao espírito. Pelo contrário, surge a suspeita de que a sensação no sentido de 'percepção por excelência' da realidade sensorial moderna e urbana, que segue os padrões do mercado medieval, não mais se expandiu". Da Revolução Francesa, vista como espetáculo, vem o significado de sensação como "muito mais o estado produzido de oscilante inquietação e entusiasmo, do cobiçar e do protestar: a efervescência social" (TÜRCKE, 2010: 117).

A compulsão a emitir soma-se à condição de existência e é uma marca da globalização microeletrônica. Assim, é necessário chamar a atenção para não sucumbir, ou seja, conforme Türcke (2010: 59), "não ser percebido significa estar 


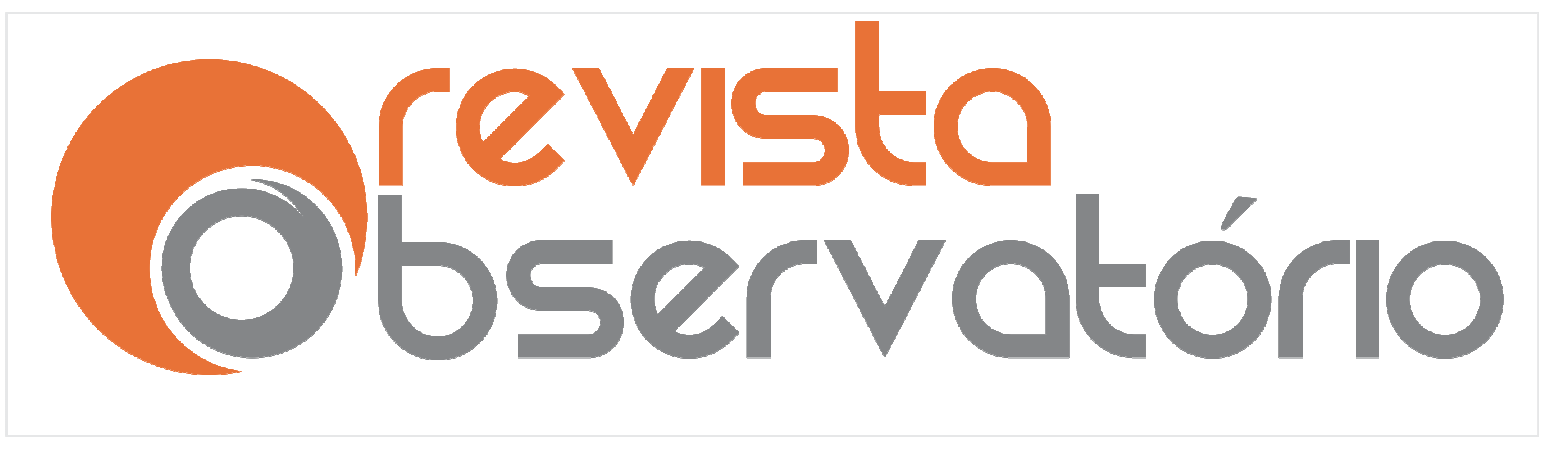

ISSN n² 2447-4266

Vol. 3, n. 3, Maio. 2017

DOI: http://dx.doi.org/10.20873/uft.2447-4266.2017v3n3p415

de fora, e estar de fora é como estar morto em um corpo vivo", logo, "temos que incluir todos: os idosos e os enfermos, os desempregados e os presidiários, os que pensam e os que agem diferente".

No entanto, a integração social não foi, desde os primórdios, de maneira alguma idílio. $\mathrm{Na}$ tentativa de dominar o terror vieram os rituais de sacrifício, a caça, a iniciação e a conjuração que podem assim ser vistos como procedimentos de adaptação dos seres humanos. O capitalismo, por sua vez, em sua fase de emergência, promoveu a desagregação, pois segundo Türcke (2010: 61), parte considerável da população foi retirada das terras de seus ancestrais, os trabalhadores foram separados de seus instrumentos, "mas também o avaro de suas posses, o nobre de suas propriedades de família, o cavalariço do equipamento militar mais moderno, assolando as estruturas tradicionais da nobreza, guildas, cidades, vilarejos e famílias".

"O ponto a partir do qual esse turbilhão se formou era o velho $\mathrm{e}$ conhecido mercado, mas com uma nova função: não mais como local para troca de mercadorias, mas como instância de socialização" (TÜRCKE, 2010: 61). O potencial de sucção do mercado fez com que os homens ou suas mercadorias se colocassem à venda, sem garantir se seriam vendidos, fez com que a compra e a escolha caminhassem juntos, que o inútil fosse rotulado de invendável, ou seja, o poder de seleção do mercado tem como precondição o poder de integração. A compulsão à emissão, por sua vez, corresponde à força de sucção do mercado sob condições microeletrônicas. Nas palavras de Türcke (2010: 66-7):

A aparelhagem midiática ofusca a irradiação de cada organismo, despotencializando-o até ele se tornar irreconhecível, assim também o faz em relação à capacidade de percepção. Como parecem insossos os estímulos do meio imediato em comparação com aqueles que, berrantes, continuamente cintilam na tela; como fica entediante a 


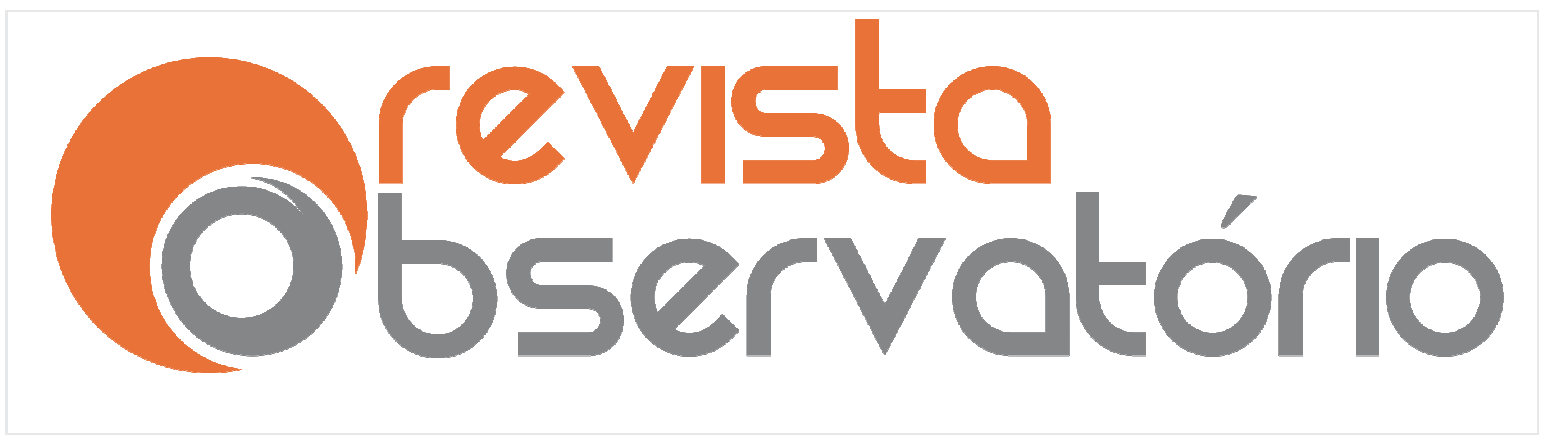

ISSN n² 2447-4266

Vol. 3, n. 3, Maio. 2017

DOI: http://dx.doi.org/10.20873/uft.2447-4266.2017v3n3p415

rotina de cada um diante de tudo aquilo de excitante que as mídias incessantemente veiculam. Os estímulos do ambiente do dia a dia não são páreo para a torrente de excitação midiática do espetacular; eles ficam abaixo do limite do que o aparato sensorial pode absorver, possuem um pobre aqui e agora, mas nenhum "aí". Representam estímulos de menos para serem percebidos. A torrente de excitação, porém, representa estímulos demais. Ela coloca o organismo na situação paradoxal de não ser mais capaz de transformar os puros estímulos em percepção.

Assim, há dois aspectos envolvidos com a luta pelo "ai". O primeiro refere-se à luta pela presença midiática - a luta para ser percebido - o segundo, é a luta pela percepção. A percepção pertence ao organismo como aquilo que lhe é mais próprio, mas evapora-se em meio a uma quantidade imensa de estímulos visuais.

Constata-se que "cada imagem, cada som luta pelo seu próprio "aí", de forma que imagens e sons se sucedam uns aos outros cada vez mais rápida e violentamente" (TÜRCKE, 2010: 67). A tremenda aceleração toma todos os campos. "Mas a força de atração é generalizada, a crescente movimentação das imagens manifesta a desconfiança contra o poder da imagem individual. Está apenas "aí", na medida em que a atenção está voltada para ela. Quando some, um outro "aí", uma nova imagem tem que surgir" (TÜRCKE, 2010: 67). Em relação ao correlato fisiológico, Turcke (2010: 68), explica que "as sensações que agitadamente tomam o organismo, fazendo-se sentir em todas as suas fibras, e que parecem dar-lhe de volta a percepção subtraída, o sentimento pleno de si, são precisamente aquelas que os anestesiam".

Conforme esclarece o mesmo autor, o que se dá é que quanto mais profundamente as impressões penetram o sistema nervoso, tanto mais passam a organizar a percepção, logo, do ponto de vista fisiológico, parece impossível 


\section{Observisto}

ISSN n² 2447-4266

Vol. 3, n. 3, Maio. 2017

DOI: http://dx.doi.org/10.20873/uft.2447-4266.2017v3n3p415

vencer a luta pela percepção em meio a infinidade de sensações audiovisuais a que nos submetemos, via de regra, nos dias atuais.

No percurso da sensação ou na construção dos seus significados, vale enfatizar que, segundo Türcke (2010: 171), "a nuança de significado mais explosiva evidenciada no conceito de sensação foi sem dúvida a de inquietude, efervescência, revolta, razão pela qual a Revolução Francesa pode, em todos os sentidos, ser considerada a sensação de sua época". No entanto, a sensação primeira foi o pavor, o que significa que ao adentrar a seara especificamente humana, ela se inflacionou ao extremo, sendo que com a repetição, a excitação foi exercitada e o exercício singular de torná-lo familiar pela repetição, de temperar sua torrente de excitação culminou no que "hoje se evidencia como sensório humano e que parece transmitir-se de geração para geração como um conjunto de certas formas de percepção e presentificação mais ou menos interligadas" (TÜRCKE, 2010: 170). Assim, "impõe-se o pensamento de que a via de fuga que afasta a sociedade moderna em ritmo high-tech de suas origens arcaicas leva justamente de volta para elas" (TÜRCKE, 2010: 171), ou seja, lembrando que revolta também significa "rodar para trás".

Como adverte Losso (2014), o entendimento da sensação na sociedade contemporânea requer um olhar mais atento para outro conceito moderno, o de vício. O único recurso para sobreviver na sociedade excitada é viciar-se em grandes doses de estímulos audiovisuais. O vício necessita da descrença para firmar-se. "O viciado sabe que a substância com a qual ele se agarra não fornece um apoio verdadeiro, mas ele não tem alternativa e nele se aferra" (TÜRCKE, 2010: 246). O vício, que nasceu com a separação da festa e do frenesi, pois o ciclo de festas, característico de todas as formas sociais pré-modernas, "estruturou os cursos do ano e da vida, determinou também os ciclos dos 


\section{Observatório}

ISSN n² 2447-4266

Vol. 3, n. 3, Maio. 2017

DOI: http://dx.doi.org/10.20873/uft.2447-4266.2017v3n3p415

frenesis que fazia com que a comunidade festiva como que biorritmicamente regressasse com maior ou menor frequência ao cotidiano apático" (TÜRCKE, 2010: 234).

Mas, seria possível vencer este vício? Isto seria possível com a suspenção da torrente de estímulos audiovisuais que nos impregna? Para Losso (2014), a proteção contra os estímulos, que antes era apenas um fundamento neurológico da consciência, agora se tornou condição de sobrevivência. As pessoas precisam manter a capacidade de concentração, de parar e refletir.

Vejamos como os conhecimentos sobre os signos e suas classificações, bem como sobre seus possíveis efeitos, na perspectiva da semiótica peirceana, podem contribuir para dirimir ou amenizar os efeitos dos choques audiovisuais.

\section{Das Ideias Peirceanas: Diagramas e Níveis De Consciência}

Na Gramática Especulativa ${ }^{3}$, um dos ramos da Semiótica ou Lógica, encontra-se a classificação dos signos. O signo "'representa' algo para a ideia que provoca ou modifica. Ou seja, é um veículo que comunica à mente algo do exterior. O 'representado' é o seu objeto; o comunicado, a significação, a ideia que provoca, o seu interpretante" (CP 1.339). Segundo Drigo e Souza (2013), de acordo com Peirce, o signo pode ser classificado conforme o que $\mathrm{O}$ fundamenta, que pode ser a qualidade; o fato de ser um existente, um singular; ou o caráter de lei, de regras compartilhadas numa cultura e, sendo assim, é denominado, respectivamente: qualissigno, sinsigno e legissigno; na relação

\footnotetext{
${ }^{3}$ A Semiótica ou Lógica, como um dos ramos das Ciências Normativas, é a lógica no sentido amplo. São três os seus ramos e cada um depende dos que o precedem; o primeiro, Gramática Especulativa, trata do estudo dos signos propriamente ditos, das classificações dos signos, bem como descreve e analisa os diversos tipos de signos; o segundo, Lógica Crítica, se ocupa dos tipos de raciocínio: abdução, dedução e indução, enquanto que o terceiro, Retórica Especulativa, "estuda os métodos que deveriam ser utilizados na investigação, na exposição, e na aplicação da verdade" (CP 1.444).
} 


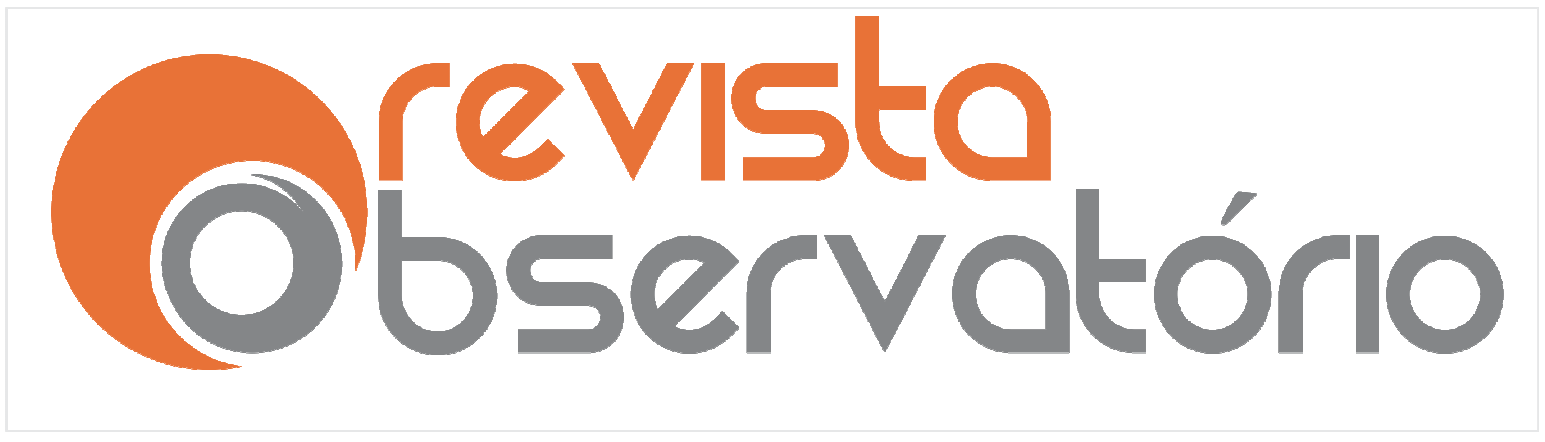

ISSN n² 2447-4266

Vol. 3, n. 3, Maio. 2017

DOI: http://dx.doi.org/10.20873/uft.2447-4266.2017v3n3p415

com o objeto, ou o que o signo representa, classifica-se em ícone, índice ou símbolo e, na relação com o interpretante, ou o efeito do signo, em rema, dicente e argumento.

Tomamos como foco a classificação do signo na relação com o objeto, mais especificamente, as divisões do ícone (Fig. 1). Os hipoícones (ou signos icônicos), por sua vez, apresentam-se em três modalidades: imagem, diagrama e metáfora. Uma delas, como exemplo, um diagrama (Fig. 1), foi elaborado a partir da classificação do ícone empreendida por Santaella e Nöth (2001).

Figura 1: Classificação dos signos na relação com o objeto

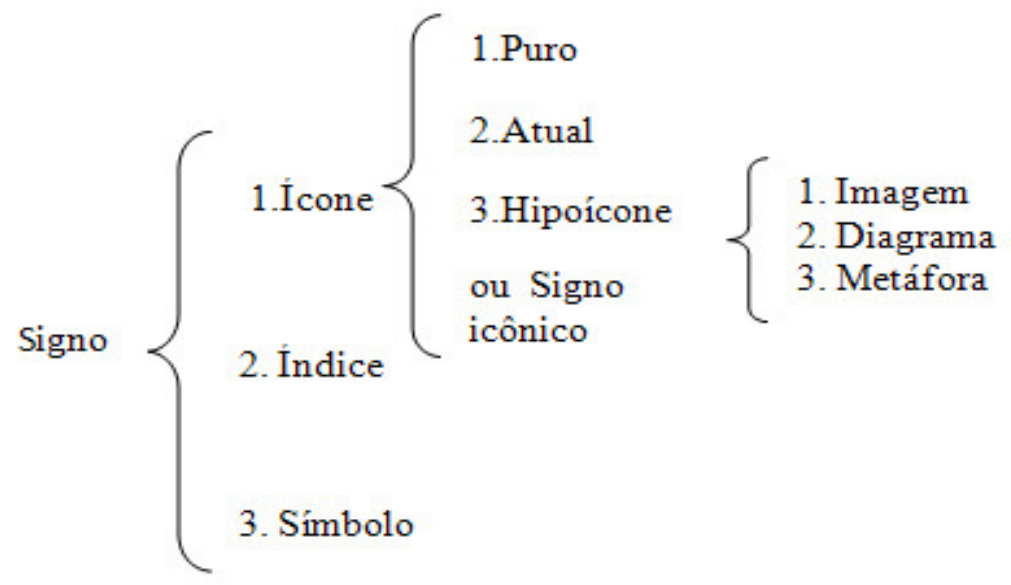

Fonte: Drigo e Souza (2013, p. 95)

Não vamos tratar de todas as subdivisões do signo, mas podemos anunciar em linhas gerais que o hipoícone (ou signo icônico), terceiro nível do ícone - refere-se a algo que já se apresenta como signo, pois representa algo. Regido pelas relações de comparação, o signo icônico alude, faz vir à mente ou 


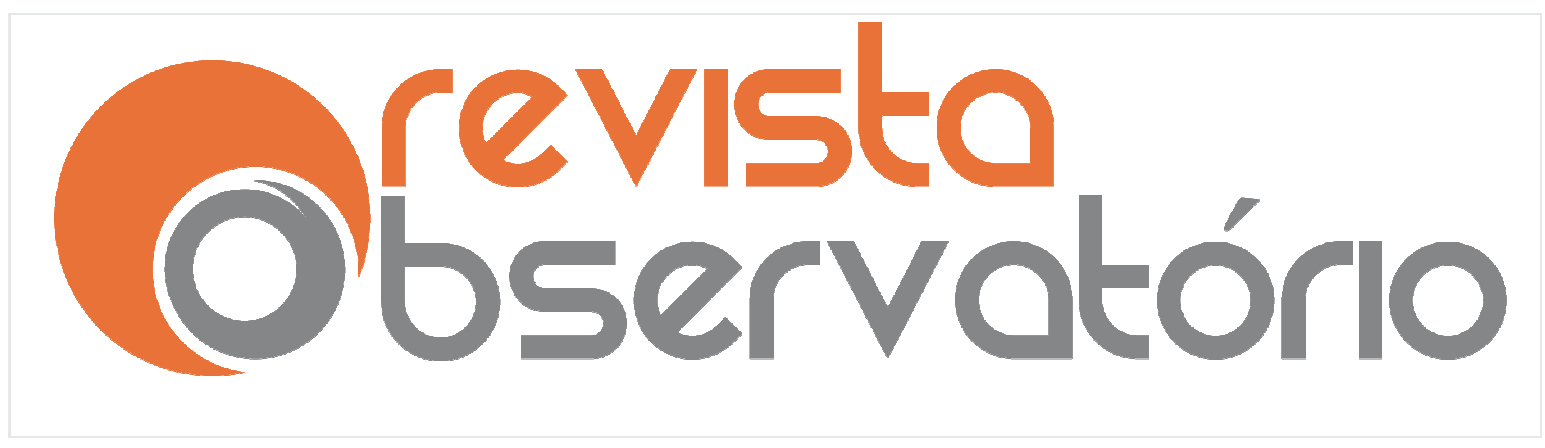

ISSN n² 2447-4266

Vol. 3, n. 3, Maio. 2017

DOI: http://dx.doi.org/10.20873/uft.2447-4266.2017v3n3p415

propõe o objeto por relações de semelhança. São três as facetas do hipoícone:

1. imagem; 2. diagrama e 3. metáfora. Ao sistematizar cada uma dessas facetas,

Peirce assim as define:

Hipoícones podem ser divididos de acordo com o modo de primeiridade dos quais eles participam. Aqueles que participam das qualidades simples, ou a primeira Primeiridade, são imagens; aqueles que representam as relações, principalmente diádicas, ou assim considerada, das partes de uma coisa por relações análogas em suas próprias partes, são diagramas; aqueles que representam o caráter representativo de um signo, exibindo um paralelismo com outra coisa, são metáforas (CP 2.277).

Os hipoícones, de um lado, produzem efeitos vinculados ao estado de contemplação, deixam o intérprete em um nível de consciência porosa, frágil, distante do autocontrole. É a seara das conjeturas, das hipóteses. De outro, nas palavras de Peirce (CP 2.278):

A única maneira de comunicar diretamente uma ideia é por meio de um ícone; e cada método indireto de comunicar uma ideia deve depender de seu estabelecimento mediante a utilização de um ícone. Assim, cada afirmação deve conter um ícone ou conjunto de ícones, ou então deve conter signos cujo significado só é explicável por ícones.

Considerando-se que, para Peirce, os interpretantes operam modificações na consciência (CP 5.485), se há semiose - ação dos signos -, há algum nível de consciência. Tal como nos explica Peirce, três são os níveis de consciência:

As categorias da consciência são três: primeira, sentimento, a consciência que pode ser incluída em um instante de tempo, consciência passiva de qualidade, sem recognição ou análises: segundo, consciência de uma interrupção no campo da consciência, sentido de resistência, de um fato externo; terceiro, consciência sintética, ocorrendo no tempo, sentido de aprendizagem, pensamento (CP 1.377). 


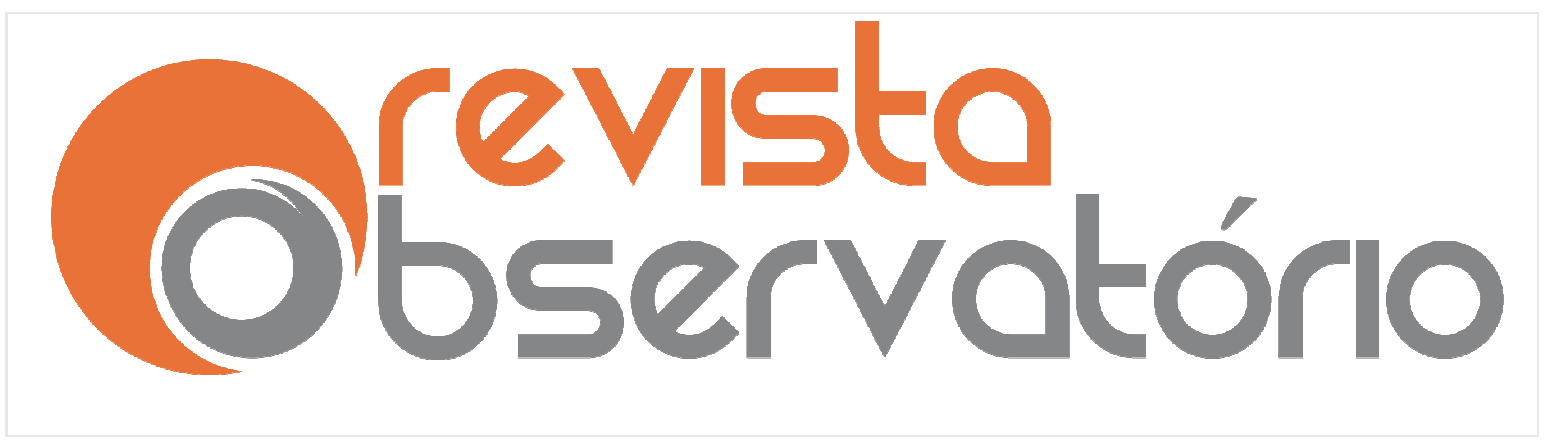

ISSN n² 2447-4266

Vol. 3, n. 3, Maio. 2017

DOI: http://dx.doi.org/10.20873/uft.2447-4266.2017v3n3p415

De acordo com o relato em CP (1.387), quando da sua investigação na Psicologia em busca de comprovar as categorias fenomenológicas, consideradas como conceitos simples e aplicáveis a quaisquer objetos, Peirce substitui as três faculdades dessa ciência: sentimento, vontade e cognição, por uma nova tríade. Sentimento, ou consciência imediata ou simples; sentimento de polaridade ou consciência dual e consciência sintética. Segundo Peirce,

[...] se nós aceitamos estes como os modos de consciência
fundamentais elementares, eles possibilitam uma explicação
psicológica das três concepções lógicas de qualidade, relação e
síntese ou mediação. A concepção de qualidade, a qual é
absolutamente simples nela mesma e, contudo, observada nessas
relaçães ela parece ser repleta de variedade, surgiria em qualquer
momento quando sentimento ou consciência singular se torna
proeminente. A concepção de relação vem da consciência dual ou
sentido de ação e reação. A concepção de mediação emerge da
consciência plural ou sentido de aprendizagem (CP 1.378).

Ao tratar da consciência sintética, considerando os níveis de relações tríadicas, Peirce propõe três tipos de consciência sintética, a que inclui (a) sentido de similaridade ou semelhança; (b) o sentido de conexão real, e (c) o sentido de aprendizagem. Nessa classificação há ênfase na compulsão, embora essa seja pertinente à segundidade. Observemos o diagrama (Fig. 2). 


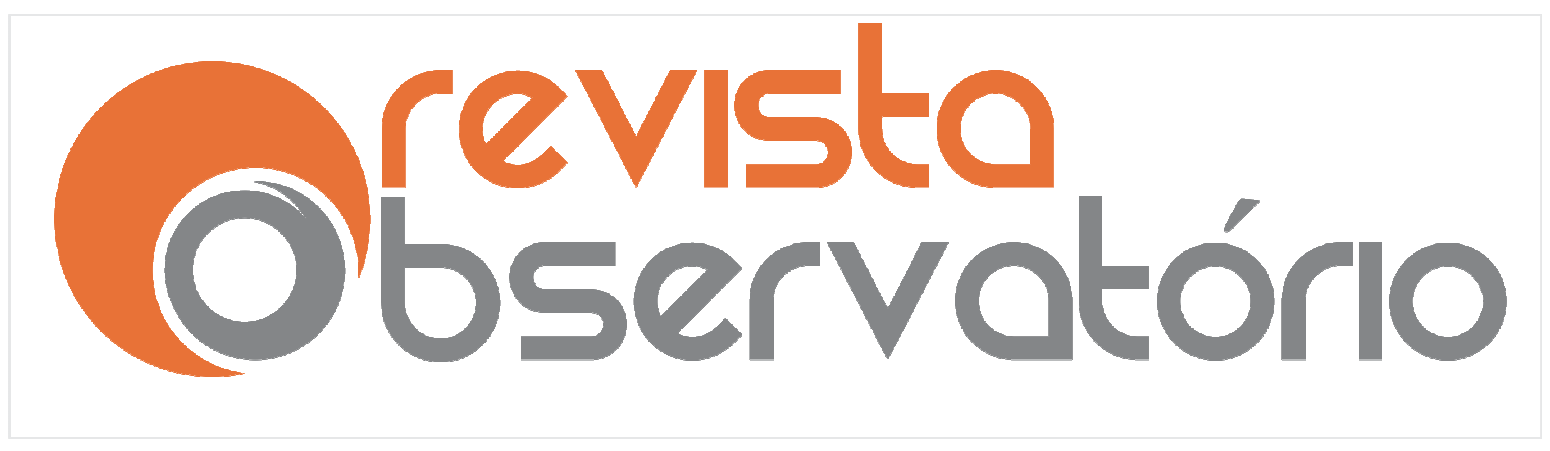

ISSN n² 2447-4266

Vol. 3, n. 3, Maio. 2017

DOI: http://dx.doi.org/10.20873/uft.2447-4266.2017v3n3p415

Figura 2: Diagrama para os níveis de consciência

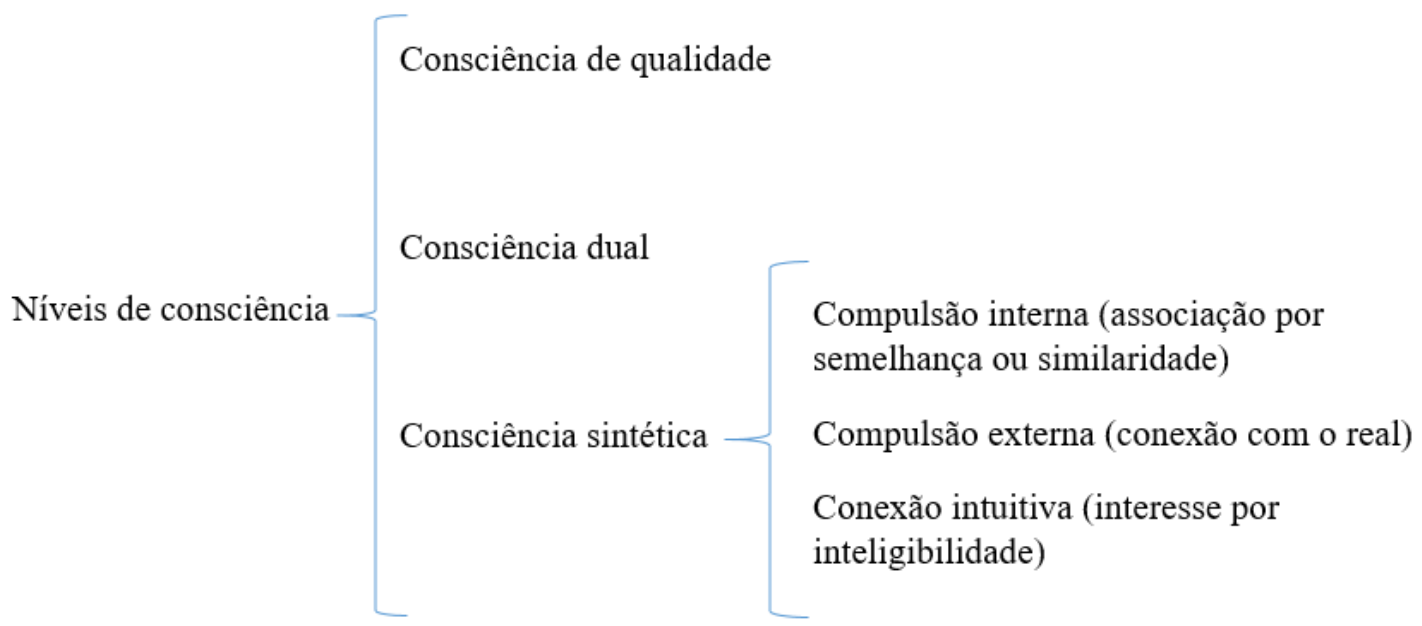

Fonte: Elaborado pela autora a partir das ideias de Peirce tratadas neste artigo.

Peirce (CP 1.383) vale-se da ideia de compulsão para explicitar os três tipos de consciência sintética e menciona que o nível maior de síntese não se dá com atração de feeling ou representações deles, nem por força de necessidade, mas por interesse de inteligibilidade. A conexão, nesse caso, se dá por intuição - algo não contido nos dados, nas informações -, que pode ser compreendida como a consideração, no sentido de atentar para, de pôr o abstrato em uma forma concreta.

Segundo as hipóteses de Peirce (CP 1. 388 a 1. 391), a compulsão por similaridade se dá quando a parte de uma ideia é considerada idêntica à parte ou à outra ideia, o que corresponde ao sentimento peculiar à excitação de uma ou mais células nervosas; já a compulsão de pensar que dois elementos da experiência, particularmente distintos, se vinculam, se dá por força da forma de 


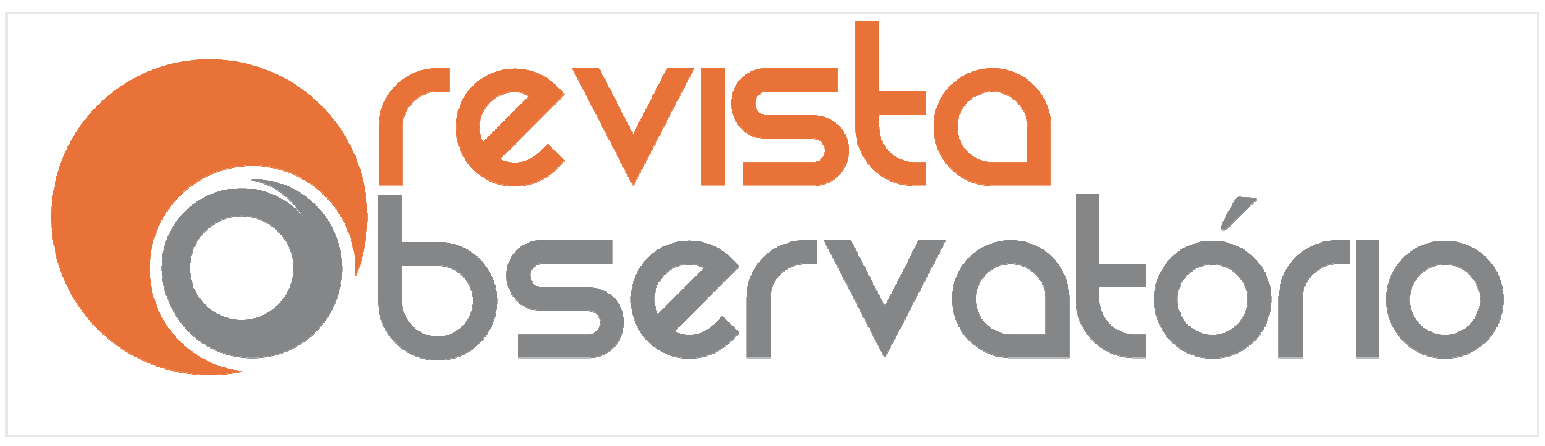

ISSN n² 2447-4266

Vol. 3, n. 3, Maio. 2017

DOI: http://dx.doi.org/10.20873/uft.2447-4266.2017v3n3p415

descargas elétricas, enquanto a conexão por força da intuição se dá pela propriedade mais característica do sistema nervoso, o poder de tomar hábitos.

Vejamos em diagrama (Fig. 3) as relações estabelecidas entre as ideias mencionadas e o que delas apreendemos. Para tentar alcançar a brevidade, a concisão e nem tanto a veemência como a dos comerciais, passamos aos resultados advindos na confluência das ideias dos autores mencionados.

\section{Sobre O Diagrama E A Imagem}

Ao percorrer o diagrama (Fig. 3), em busca de explicações, podemos enfatizar que estamos diante de uma modalidade de representação lacônica, suscetível de maior desenvolvimento, pois os elos entre as suas partes sugerem algumas relações entre elas. Assim, em termos lógicos, coloca a mente do intérprete ao sabor de associações e como num enigma, pode incitar a busca por respostas e promover, portanto, descobertas. 


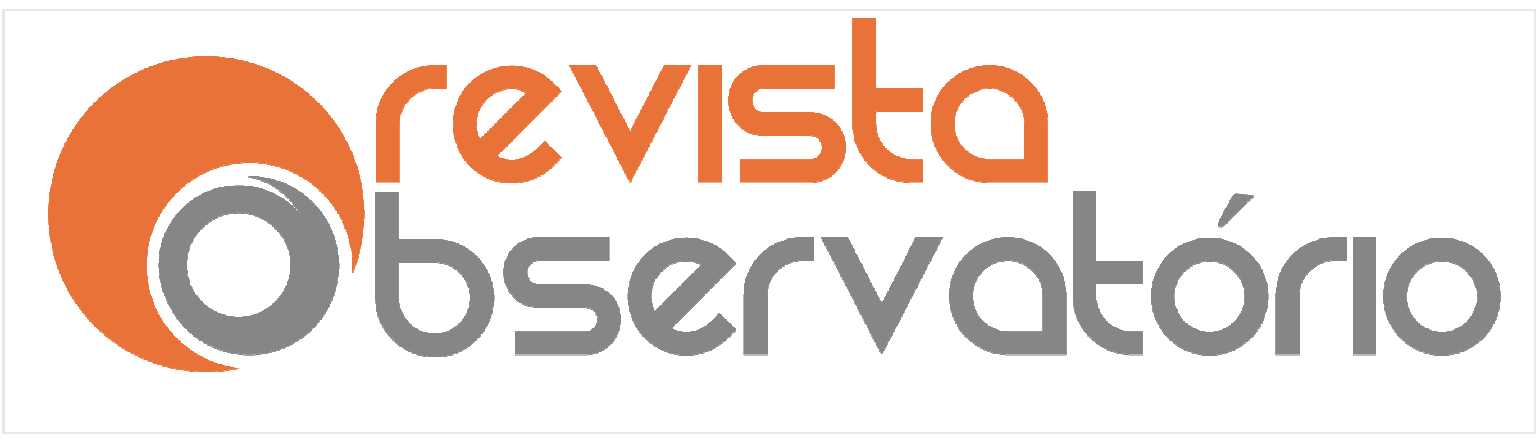

ISSN n² 2447-4266

Vol. 3, n. 3, Maio. 2017

DOI: http://dx.doi.org/10.20873/uft.2447-4266.2017v3n3p415

Figura 3: Diagrama exibindo o caminhar das reflexões que constam no artigo

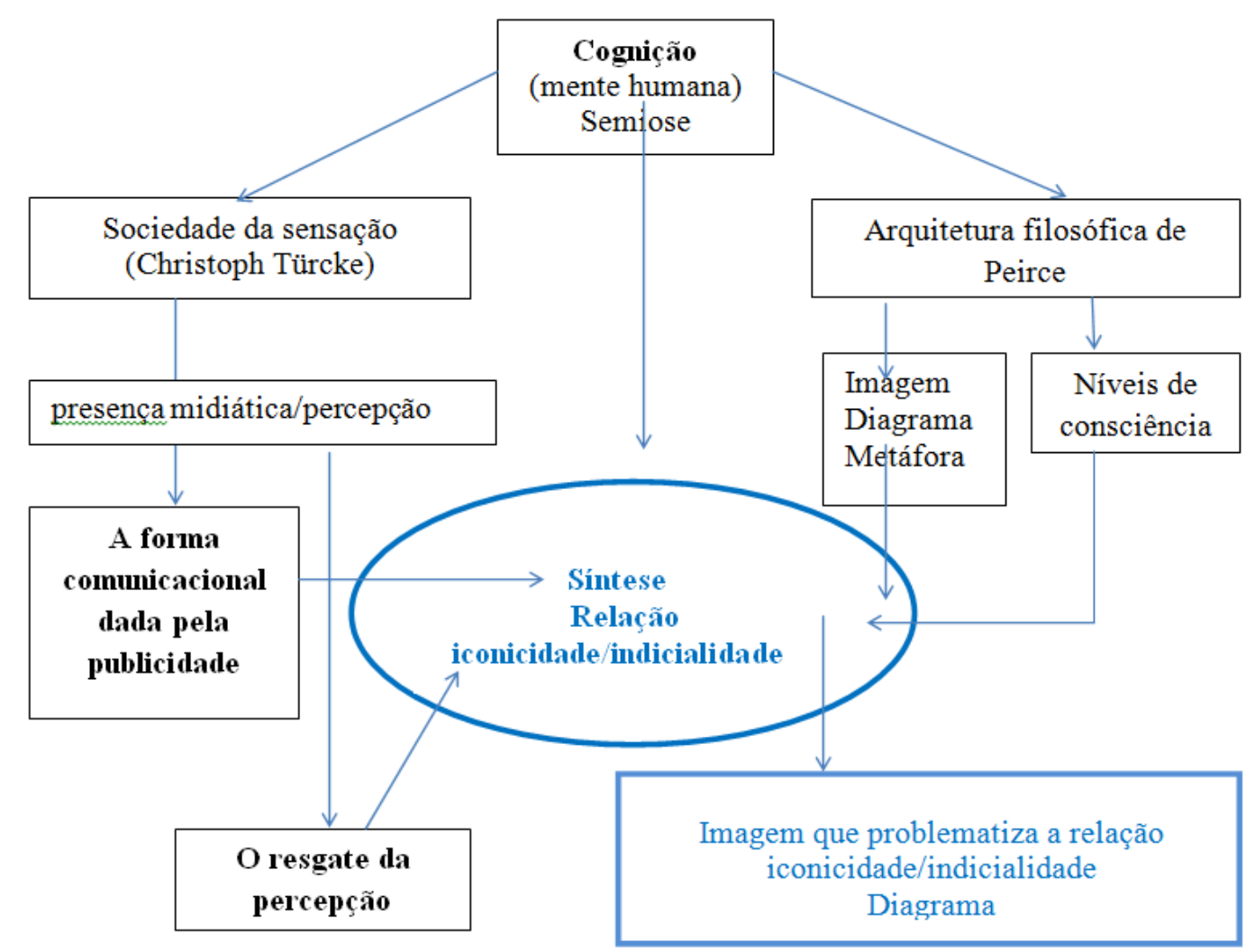

Fonte: Elaborado pela autora a partir do texto em elaboração

Ele tanto mostra que o seu produtor caminha por todos os elos sugeridos, ou seja, que a sua elaboração requer conhecimento do assunto, do conceito, como pode ser fruto de ideias que anseiam por conexões. Ela tanto vem de um estado posterior ao conhecimento do assunto ou de um conceito como pode ser fruto da abdução, modalidade de raciocínio em que se adivinham possíveis elos entre as partes do todo ou entre ideias e conceitos, ou 


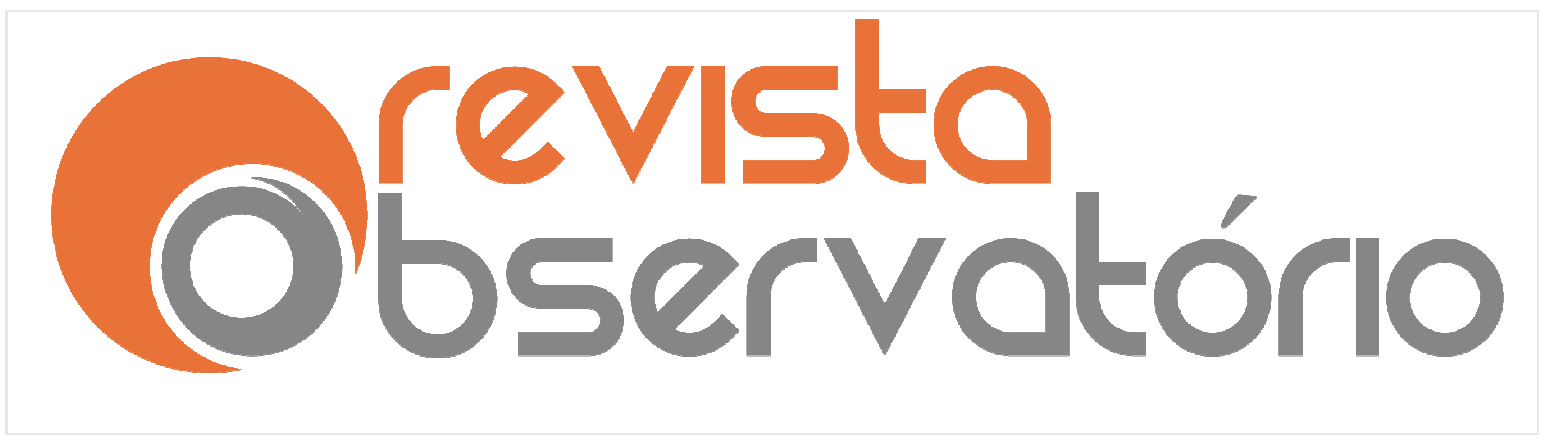

ISSN n² 2447-4266

Vol. 3, n. 3, Maio. 2017

DOI: http://dx.doi.org/10.20873/uft.2447-4266.2017v3n3p415

possíveis soluções de problemas - hipóteses-, mas que ainda precisam ser comprovadas.

Constata-se, portanto, num primeiro momento, que dois tipos de síntese são possíveis, os quais arriscamos chamar de "síntese de insight" - fruto de conexões pressentidas ou adivinhadas - e, síntese de recognição, vinculadas à primeiridade e à terceiridade, respectivamente. Observando a divisão da consciência sintética dada por Peirce, constata-se também que há um segundo tipo de síntese, vinculado à segundidade. Estas divisões da síntese lembram as propostas por Kant, na Crítica da Razão Pura. Mas, isto demanda um estudo aprofundado, tarefa que deixamos para um estudo posterior.

O diagrama comunica com brevidade e sugere precisão, exatidão e apuro. A veemência, outro atributo do comercial, pode ser encontrada na energia e no vigor que vêm dos vínculos exibidos. Embora comunique de modo breve, ele requer um olhar demorado, pode suscitar o interesse pela legibilidade. Isto é notório quando ao percorrer o diagrama, o usuário/intérprete, sem se dar conta, começa a formular questões. O diagrama, portanto, pode levar a mente do usuário/intérprete, pelos seus efeitos ou interpretantes, a atualizar a consciência sintética. Para comparar um diagrama com um texto (linguagem escrita), vale enfatizar, conforme Merleau-Ponty (1994), que a maravilha da linguagem está no fato de que ela provoca o esquecimento.

O papel, as letras sobre o papel, meus olhos e meu corpo estão presentes como o mínimo de teatralização necessária para uma operação invisível. A expressão se apaga diante do expresso, e o porquê de seu papel mediador pode passar despercebido (...). Esta certeza que nós temos de alcançar, para além da expressão, uma verdade que pode ser separada dela e da qual a expressão é apenas a roupagem ou a manifestação contingente, é justamente o que a linguagem instalou em nós (MERLEAU-PONTY, 1994: 458). 


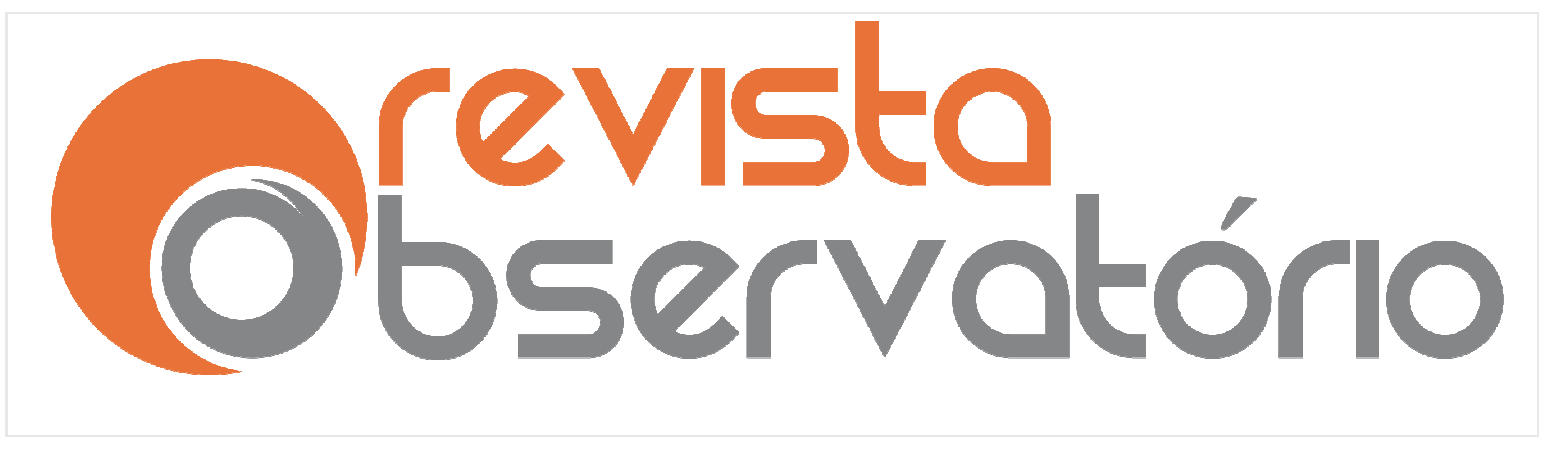

ISSN n² 2447-4266

Vol. 3, n. 3, Maio. 2017

DOI: http://dx.doi.org/10.20873/uft.2447-4266.2017v3n3p415

Neste sentido, o diagrama - pela sua própria "escrita" -, pelos traços, cores ou formas, pode prender a atenção do leitor aos vínculos possíveis entre as partes de um todo, entre os elos que constroem os significados, antes de ir para os significados, que esquecem os aspectos qualitativos e referencias de um signo. Tal modo de representação, que está na seara do segundo nível da primeiridade, por isto requer mais atenção, pode romper com hábitos já cristalizados e relativos ao processo de leitura/interpretação, que tomam a expressão (os aspectos relativos à materialidade do signo) como uma mera roupagem.

No que se refere às imagens, valendo-se de A Lei da Mente, que consta em Peirce (1998), compreendemos que a continuidade da semiose - enquanto conexão entre os interpretantes - se instaura, via qualidade de sentimentos. Mas, tal continuidade deveria ser "visível" nos objetos, nas coisas, nos acontecimentos, ou seja, as marcas do objeto são imprescindíveis. Nesse sentido, a continuidade na semiose se estabelece, atrelado às imagens, quando o nível de indicialidade que prepondera é o degenerado, ou seja, quando há um jogo entre a indicialidade e a iconicidade na relação do signo com o objeto.

As representações visuais devem problematizar a relação iconicidade/indicialidade, o que quer dizer que nem tanto a nitidez nem tanto a pura sugestão. Elas precisam ter marcas do real e construir jogos com elementos qualitativos, tais como forma, cor, textura, movimento etc. para propiciar a percepção e, assim, atualizar os primeiros níveis da consciência sintética, na associação por semelhança e por contiguidade, simultaneamente. Vale enfatizar que o índice remete a algo existente, nos liga ao mundo real, chama, insiste, leva-nos até o objeto. A força envolvida neste ato não é gentil. 


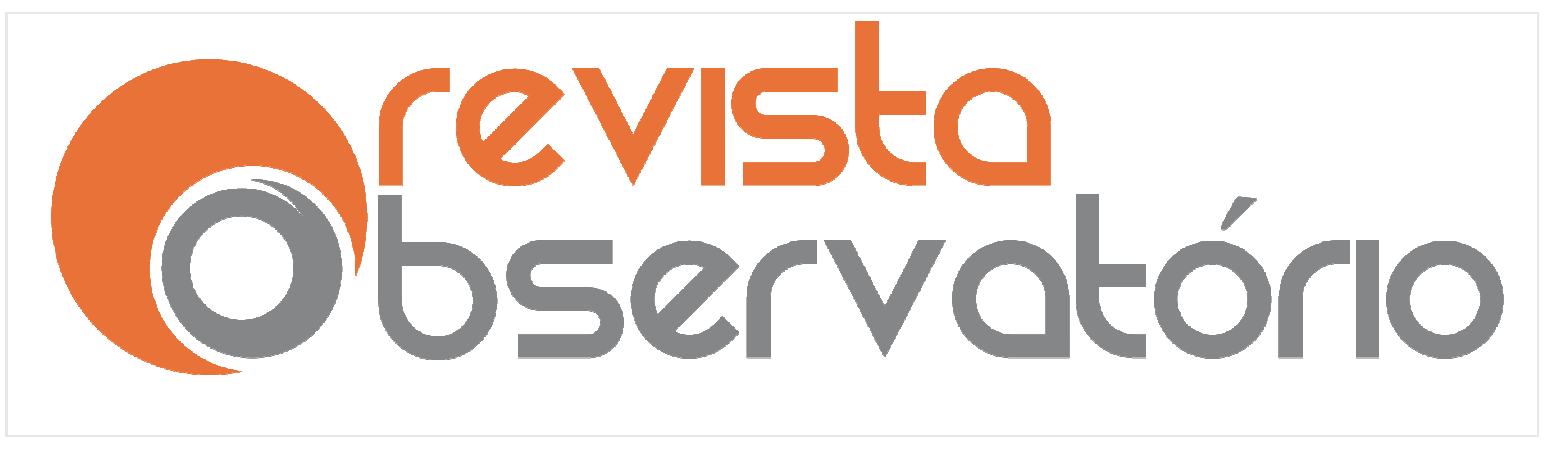

ISSN n² 2447-4266

Vol. 3, n. 3, Maio. 2017

DOI: http://dx.doi.org/10.20873/uft.2447-4266.2017v3n3p415

Ela impele, aponta, impulsiona. Segundo Peirce, o índice, "como um dedo apontando, exerce sobre a atenção uma força fisiológica real, como o poder de um magnetizador, dirigindo-a para um objeto particular dos sentidos" (CP 8.41). O índice, portanto, nas palavras de Peirce:

[...] se refere a seu objeto não tanto em virtude de uma similaridade ou analogia qualquer com ele, nem pelo fato de estar associado a caracteres gerais que esse objeto acontece ter, mas sim por estar numa conexão dinâmica (espacial inclusive) tanto com o objeto individual, por um lado, quanto, por outro lado, com os sentidos ou a memória da pessoa a quem serve de signo (CP 2.305).

Desse modo, as representações visuais guardam o potencial significativo na sua aparência, na sua epiderme. As cores, as formas e as texturas, bem como o jogo com esses elementos aliados ao poder de indicar algo do mundo - por vestígios, por rastros-, produzem efeitos, ou seja, propiciam a cognição, desencadeiam a semiose.

Para vencer a velocidade das imagens ou dos choques imagéticos, que contribuem para que a percepção se dissipe, que fazem com que os sentidos fiquem dormentes, conforme explica Türcke, buscam-se, portanto, as imagens que amenizem os efeitos da constatação, sem deixar de provocar sensações, mas as que arrebatam afetos e paixões, que sejam veementes.

As duas modalidades de hipoícone mencionadas - imagem e diagrama -, com as características mencionadas podem contribuir para que a cognição se dê, pois guardam aproximações com a forma comunicacional dada pela publicidade e contribuem para resgatar a percepção.

Resta abordar a metáfora, o terceiro tipo de hipoícone, signo que opera no terceiro nível da primeiridade. O ponto máximo da síntese está na metáfora, que como explica Perelman e Olbretchs-Tyteca (2005), trata-se de uma analogia 


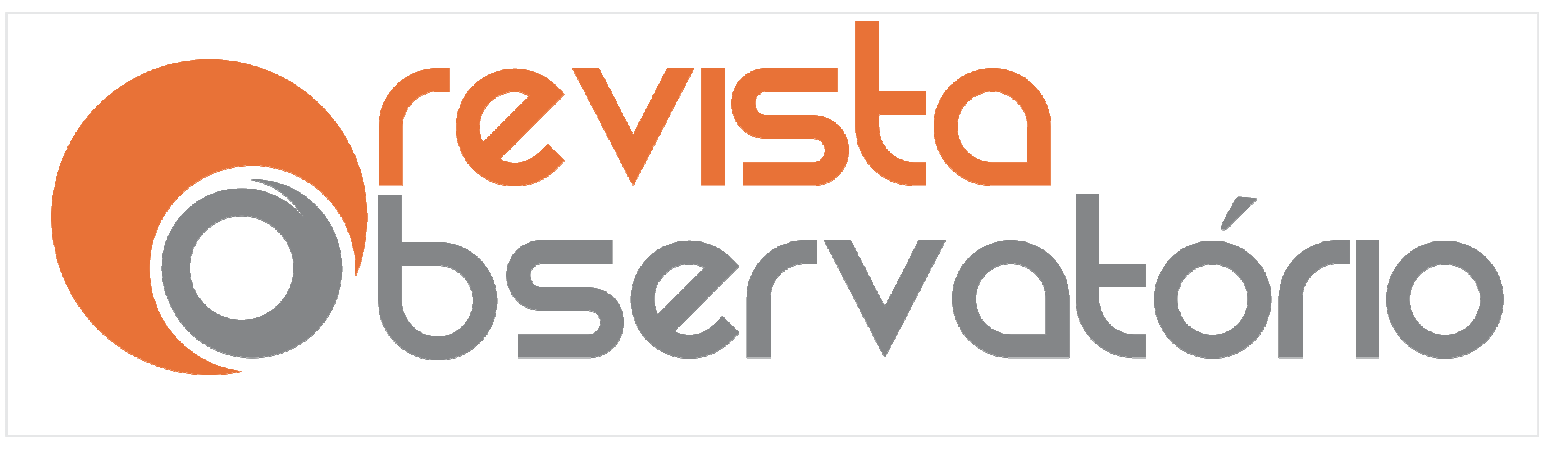

ISSN n² 2447-4266

Vol. 3, n. 3, Maio. 2017

DOI: http://dx.doi.org/10.20873/uft.2447-4266.2017v3n3p415

condensada, resultante da fusão de um elemento do foro como um elemento do tema (componentes de uma analogia ${ }^{4}$ ). As metáforas, segundo Santaella (1995: 120), "fazem o paralelo entre o caráter representativo do signo com o caráter representativo de um possível objeto [...]. Caráter representativo referese àquilo que dá ao signo poder para representar algo diverso dele".

Metáforas visuais, por sua vez, são "aquelas que, mesmo reproduzindo a aparência externa das coisas, essa aparência é utilizada apenas como meio para representar algo que não está visualmente acessível e que, via de regra, tem um caráter abstrato e geral" (SANTAELLA, 2001: 59). O sentido é alcançado por um fazer operativo e relacional, que exige uma mente interpretadora capaz de gerar a semiose das formas simbólicas.

Tais modalidade de representação vão ao encontro de um formato que requer que a comunicação opere de modo breve. Podem contribuir para que na percepção, a coisa percebida venha com seus aspectos qualitativos, o que propicia a contemplação e a passagem para o nível da consciência sintética - a da cognição propriamente dita - de modo suave, sem choques.

\section{Considerações Finais}

A semiose, quando o objeto é posto para o intérprete, nas modalidades de representação ou tipos de signo - a imagem e o diagrama -, demanda, da parte do intérprete, contemplação e atenção concentrada. Isto parece paradoxal considerando-se que estamos habituados a choques audiovisuais e que fazem

\footnotetext{
${ }^{4} \mathrm{Na}$ esteira de Perelman e Olbretchs-Tyteca (2005), uma analogia é constituída de duas partes: tema e foro, com dois termos em cada uma. Sejam A e B os termos do tema e C e D, os do foro. $O$ valor argumentativo de uma analogia pode ser posto em evidência se a tomarmos como uma similitude de estruturas, cuja fórmula é a seguinte: $A$ está para $B$ assim como $C$ está para $D$, ou ainda, A : B :: C: D. Sobre o tema repousa a conclusão e sobre o foro se assenta 0 raciocínio. Assim, o foro é mais conhecido que o tema, cuja estrutura ele deve esclarecer.
} 


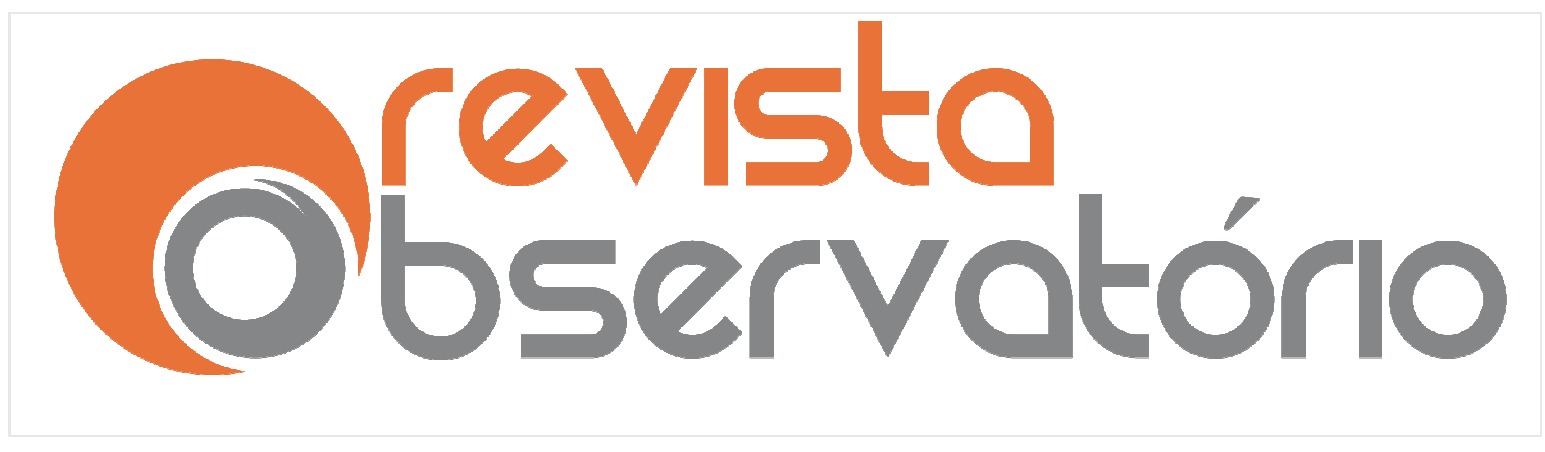

ISSN n² 2447-4266

Vol. 3, n. 3, Maio. 2017

DOI: http://dx.doi.org/10.20873/uft.2447-4266.2017v3n3p415

com que a percepção se evapore diante da necessidade (quase que como vício) de um novo choque...

Tal necessidade, que demanda outro choque ainda mais intenso e outros, sem interrupções, produzindo certa dormência (dos sentidos), pode ser amenizada com a proliferação de signos que suscitem a contemplação e a atenção. Vencer a luta pela percepção é necessário, pois como alerta Peirce, ela é a porta de entrada de todo pensamento lógico, de toda cognição.

A partir de possíveis vínculos entre as ideias apresentadas e na confluência delas, anunciamos a necessidade do desenvolvimento da capacidade de síntese, por parte dos intérpretes, bem como a amenização dos efeitos do signo enquanto índices em detrimento dos ícones, ou a problematização desta relação, por parte dos produtores de signos. Isto porque a síntese permite dar conta do conteúdo, dos conceitos, por meio de formas, enquanto o jogo iconicidade/indicialidade propicia o que Peirce denomina de conexão intuitiva, que contribui para a permanência da consciência no terceiro nível, o da inteligibilidade. A síntese, por sua vez, expressa em diagrama, acata a uma forma de comunicação que comporta a brevidade, a concisão, no entanto, é denso e com potencial para desencadear um processo intelectivo que gera conhecimento novo ou propicia o crescimento de ideias, a fixação de conceitos.

Infográficos, fotos que se transformam com aplicativos no Instagram, a telenovela Meu pedacinho de chão, produzida e exibida pela Rede Globo entre abril e agosto de 2014, são exemplos de produtos midiáticos que aderem a um ou outro atributo mencionado.

Por fim, consideramos que as reflexões apresentadas permitem conjeturar sobre a importância de lançar um novo olhar para a publicidade, 


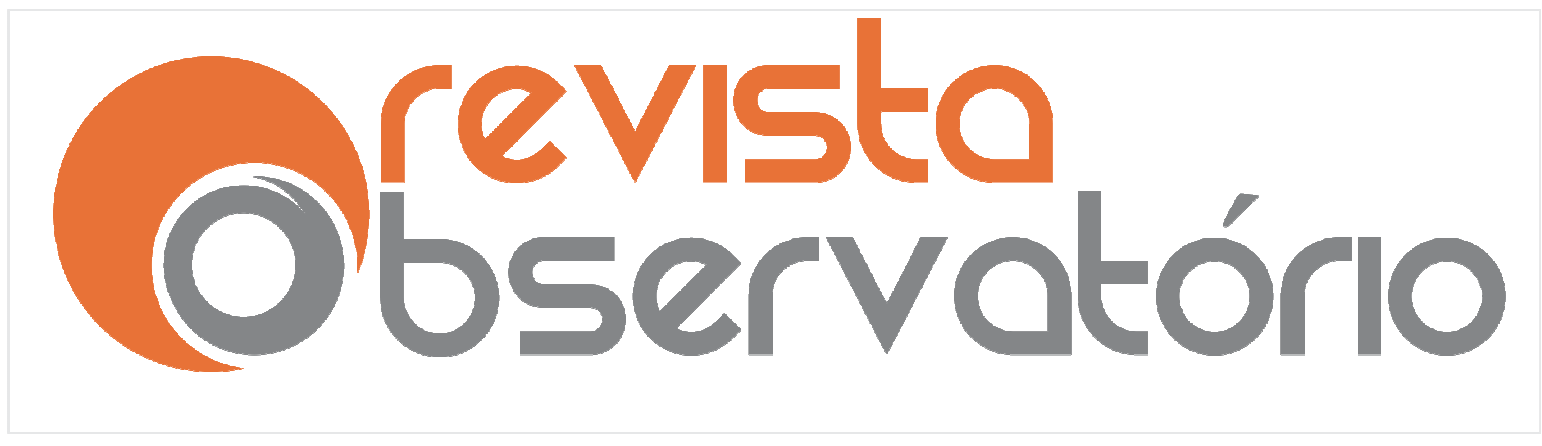

ISSN n² 2447-4266

Vol. 3, n. 3, Maio. 2017

DOI: http://dx.doi.org/10.20873/uft.2447-4266.2017v3n3p415

fundamentado no conceito de dispositivo. Mas esta tarefa deixamos para um outro artigo.

\section{Referências}

DRIGO, Maria O. e SOUZA, Luciana. C. P. de. Aulas de semiótica peirceana. São Paulo: Annablume, 2013.

LOSSO, Eduardo Guerreiro Brito. Sacralização e profanação modernas: leituras de Marx por Christoph Türcke. Revista de Estudos Universitários (REU), Sorocaba, SP, v. 40, n. 1, p. 189-203, jun. 2014.

MERLEAU-PONTY, M. Fenomenologia da percepção. São Paulo: Martins Fontes, 1994.

PEIRCE, Charles S. The Collected Papers of Charles Sanders Peirce. C. Harsthorne \& P. Weiss Ed. (Vols. I-VI). Cambridge, Mass. Harvard University Press, 1931-1958.

Antologia Filosófica. Portugal: Casa da Moeda, 1998.

PERELMAN, Chaim; OLBRECHTS-TYTECA, Lucie. Tratado da argumentação: a nova retórica. São Paulo: Martins Fontes, 2005.

SANTAELLA, Lucia e NÖTH, Winfried. Imagem: Cognição, Semiótica, Mídia. São Paulo: Iluminuras, 2001.

SANTAELLA, Lucia. A teoria geral dos signos. São Paulo: Ática, 1995.

TÜRCKE, Christoph. Sociedade excitada: filosofia da sensação. Campinas/SP: Editora da Unicamp, 2010. 